\title{
Performance Characteristics of Mix Oil Biodiesel Blends with Smoke Emissions
}

\author{
Sanjay Mohite a*, Sudhir Kumar a and Sagar Maji ${ }^{b}$ \\ ${ }^{a}$ National Institute of Technology, Kurukshetra, Haryana, India \\ ${ }^{b}$ Delhi Technological University, New Delhi, India
}

\begin{abstract}
Fossil fuel resources are being depleted day by day and its use affects the environment adversely. Renewable energy is one of the alternate for sustainable development and biodiesel is one of the suitable alternate which can replace the diesel. The major hurdles in the successful commercialization of biodiesel are high feedstock cost and conversion technology to reduce viscosity. The choice of raw material and biodiesel production method must depend upon techno-economical view. There are some specific regions for different types of oil availability. It is therefore required to produce biodiesel from the mixture of oils to fulfill the requirements of energy demand in a particular country according to its suitability and availability of feedstock. Karanja and Linseed crops are abundantly available in India. Biodiesel was produced from a mixture of Karanja and Linseed oils by alkaline transesterification. In this experimental study, biodiesel blends of $10 \%, 20 \%$ and $30 \%$ were used with diesel in a diesel engine at a constant speed of $1500 \mathrm{rpm}$ with varying brake powers (loads) from $0.5 \mathrm{~kW}$ to $3.5 \mathrm{~kW}$ to evaluate brake thermal efficiency, brake specific fuel consumption, brake specific energy consumption, exhaust gas temperature, mechanical efficiency, volumetric efficiency, air fuel ratio and smoke opacity. They were compared with diesel and found satisfactory. BTE was found to be $28.76 \%$ for B10 at $3.5 \mathrm{~kW}$ load. Smoke opacity was also found to be reduced with all blends. Smoke opacity was found to be reduced up to $10.23 \%$ for $\mathrm{B} 10$ biodiesel blend as compared to that of diesel at 3.5kW. Experimental investigation has revealed that biodiesel produced from a mixture of Karanja and Linseed oils can be successfully used in diesel engines without any engine modification and B10 was found to be an optimum biodiesel blend in terms of brake thermal efficiency.
\end{abstract}

Keywords: biodiesel blends, karanja, linseed, mixture, brake thermal efficiency, exhaust gas temperature, volumetric efficiency, smoke opacity

Article History: Received April 14th 2016; Received in revised form June 25 ${ }^{\text {th }} 2016$; Accepted July 10 ${ }^{\text {th }} 2016$; Available online

How to Cite This Article: Mohite. S, Kumar, S. \& Maji, S. (2016) Performance characteristics of mix oil biodiesel blends with smoke emissions. Int. Journal of Renewable Energy Development, 5(2), 163-170. http://dx.doi.org/10.14710/ijred.5.2.163-170

\section{Introduction}

Monoalkyl esters of fatty acids, which is derived from vegetable oils or animal fats is known as biodiesel. Biodiesel is generally produced by transesterification. In transesterification, vegetable oil is reacted with alcohol chemically in the presence of sodium hydroxide or potassium hydroxide as catalyst (Nakpong \& Wootthikanokkhan 2010). Higher cetane number, absence of aromatic and sulfur and presence of oxygen are some of the advantages of biodiesel as compared to diesel (Pal et al. 2010). Biodiesel is renewable, non-toxic and non-polluting as compared to diesel and therefore, it is one of the best alternatives to diesel (Sinha et al. 2008). Biodiesel is sustainable on the basis of overall life cycle analysis, but the production cost of biodiesel is higher than that of diesel, which is the main hindrance for its commercialization (Abbaszaadeh et al. 2012; Bhuiya et al. 2016). First generation feedstocks (edible oils) which is utilized for food preparation can not be used as fuel in developing countries because it will create food scarcity. The utilization of arable lands for this purpose may cause environmental problems also. Keeping all these factors into consideration, Second generation feedstocks (non-edible oils) shall be used for biodiesel production (Atabani et al. 2013). The cost of

*Corresponding Author:

Email: smohite001@yahoo.com 
biodiesel feedstock derived from vegetable oils, covers the $70-95 \%$ proportion of the total cost of biodiesel production. The low cost of biodiesel production can be achieved only after proper selection of feedstock. Proper attention may be given for the selection of feedstocks which do not compete with food crops as well as which reduce greenhouse gas emissions notably. Feedstocks should be chosen for biodiesel production on the basis of low production costs and large production scale. Geographical location, regional climate and soil conditions are some of the factors of any country on which availability of biodiesel feedstocks depends (Bhuiya et al. 2016). Linseed oil, Rice bran oil, Castor oil, Jatropha oil and Karanja oils are some of the non-edible oils which are used for the biodiesel production generally in India (Barnwal \& Sharma 2005; Kumar et al. 2015).

Two step transesterification is generally used for the biodiesel production from high free fatty acid content Karanja oil (Gangil et al. 2015). Biodiesel yields depend upon the FFA content of oil. Higher yields of biodiesel in the range of 88 to $96 \%$ were obtained with low FFA content Linseed oil (Kumar et al. 2013). The average molecular weight of Linseed oil is $890 \mathrm{~g} / \mathrm{mol}$. Fatty acid composition of Linseed oil is: $52 \%$ linolenic acid, 17\% linoleic acid and 22\% oleic acid mainly (Martini et al. 2009). These fatty acids have double bonds in their chemical structure and therefore, they are known as unsaturated acids. The composition of fatty acid in Karanja and Linseed oils is shown in Table 1 (Halder et al. 2014; Popa et al. 2012; Puhan et al. 2009; Guzatto et al. 2011; Saha \& Goud 2015).

Table 1

Fatty acid composition of Karanja and Linseed Oil

\begin{tabular}{|c|c|c|}
\hline Composition & $\begin{array}{l}\text { Karanja Oil, } \\
\text { wt } \%\end{array}$ & Linseed Oil, wt\% \\
\hline $\begin{array}{l}\text { Palmitic acid } \\
\text { (C 16:0) }\end{array}$ & $12.3-22.42$ & $6.21-6.58$ \\
\hline $\begin{array}{l}\text { Stearic acid } \\
(\mathrm{C} 18: 0)\end{array}$ & $7-7.4$ & $4.43-5.63$ \\
\hline $\begin{array}{l}\text { Oleic acid } \\
\text { (C } 18: 1)\end{array}$ & $40.8-50$ & $18.5-20.17$ \\
\hline $\begin{array}{l}\text { Linoleic acid (C } \\
\text { 18:2) }\end{array}$ & $15.21-19.93$ & $14.4-17.25$ \\
\hline $\begin{array}{l}\text { Linolenic acid } \\
\text { (C18:3) }\end{array}$ & 1.98 & 51.12- 59.8 \\
\hline
\end{tabular}

The major hurdles in the successful commercialization of biodiesel are high feedstock cost and conversion technology to reduce viscosity. The choice of raw material and biodiesel production method must depend upon techno-economical view. There are some specific regions for different types of oil availability. It is therefore required to produce biodiesel from the mixture of oils to fulfill the requirements of energy demand, according to suitability and availability of feedstock in a particular country. Biodiesel was produced from the mixture of Mahua and Simarouba oils, both having high content of free fatty acids and fuel properties of its biodiesel were compared with diesel (Jena et al. 2010). It was reported that biodiesel produced by two step acid transesterification from a mixture of Karanja oils and Jatropha oils can meet the requirements of diesel fuels in the near future (Yogish et al. 2012).Ternary blends of waste cooking oil biodiesel, Karanja biodiesel and diesel were prepared to overcome the poor cold flow property of biodiesel causing starting problem in the engine. Ternary blend was found to have improved engine performance and is comparable to that of diesel (Kumar et al. 2015). Mahua oil and Simaouba oil with FFA levels of $13 \%$ and $1.43 \%$ respectively were mixed in equal proportions to reduce the consumption of methanol in the production of biodiesel. The result showed 7.19\% FFA level for mixed oil. A two step process, an acid pretreatment followed by base transesterification was followed to bring down the FFA level at around $1 \%$ to produce biodiesel (Raheman et al. 2013). It was investigated that hybrid biofuel could be prepared from local crude vegetable oils i.e. Gmelina Arborea Roxb (GAO), Mimusops Elengi Linn (MEO), Acer Laurinum Hasskarl (ALO), Thevetia Peruviana Schum (TPO) and Mesua Ferrea Linn (MFO) which does not involve any chemical reaction thus reducing the production cost of biofuels ( Bora et al. 2014).

It was found that Karanja Biodiesel has poor cold flow property due to the presence of a high percentage of saturated fatty acid in it which results in starting problems in diesel engine (Kumar et al. 2015). Karanja biodiesel and diesel was found to have BTE values in close proximity. It was reported that B100 has 2.92\% lower BTE than that of diesel (Amarnath \& Prabhakaran 2012). BSFC for $20 \%$ Karaja biodiesel blend with diesel and diesel were reported to be $0.288 \mathrm{~kg} / \mathrm{kWh}$ and 0.263 $\mathrm{kg} / \mathrm{kWh}$ respectively at full load on the diesel engine. It was concluded that BSFC for Karanja biodiesel blend was slightly higher than diesel due to the lower heating value of biodiesel (Jaichandar \& Annamalai 2012). Researchers found that the BSEC of $20 \%, 50 \%$ and $100 \%$ Karanja biodiesel blends with diesel was $2.68 \%$, $5.84 \%$ and $13.31 \%$ higher than that of diesel at 2200 rpm respectively (Sahoo et al. 2009). It was reported that Karanja biodiesel was found to have the highest EGT among all fuel blend and diesel. EGT of B100 and B20 was found to be $135^{\circ} \mathrm{C}, 136^{\circ} \mathrm{C}$ at no load and $347^{\circ} \mathrm{C}$, $339^{\circ} \mathrm{C}$ at full load respectively. It was also reported that B30 Karanja biodiesel blend was found to have better mechanical efficiency than that of diesel at lower loads (Rath et al. 2011). It was concluded that Smoke opacity of Karanja biodiesel was lower than that of diesel (Dhar \& Agarwal 2014). Presence of unsaturated acids causes improvement in cold flow properties of Linseed oil. These unsaturated acids also increase the iodine value, making Linseed oil highly viscous. It was found that Linseed biodiesel has similar BTE as compared to that of diesel and reduction in smoke emission was also reported with the use of 
linseed biodiesel in diesel engines. It was reported that specific fuel consumption and specific energy consumption were higher for Linseed biodiesel as compared to that of diesel at all loads (Puhan et al. 2009). EGT of Linseed biodiesel was found to be higher than that of diesel (Dixit et al. 2012).

It was investigated that biodiesel prepared from mixture of Polanga, Karanja and Jatropha oils showed comparable performance as compared to diesel in the conventional diesel engine with reduction in $\mathrm{CO}, \mathrm{NO}_{\mathrm{x}}$ and smoke emissions (Bora et al. 2008). It was investigated that a mixture of biodiesel blends of $25 \%$ Soybean, 25\% Canola, 25\% Palm and 25\% Diesel showed acceptable fuel properties like kinematic viscosity $4.3 \mathrm{~mm}^{2} / \mathrm{s}$, Cetane number 53 and pour point $4^{0} \mathrm{C}$ with $3 \%$ power loss and $8 \%$ higher specific fuel consumption. $\mathrm{CO}$ and $\mathrm{CO}_{2}$ emission were also reduced (Ozcanli et al. 2011). Researchers compared the performance and emission characteristics of hybrid fuel blend (diesel-anhydrous ethanol-Pongamia biodiesel) with diesel in a DI multicylinder naturally aspirated diesel engine and it was found that BTE of the hybrid fuel blend was slightly higher than that of diesel fuel. Smoke, CO, and $\mathrm{NO}_{\mathrm{x}}$ emissions were also reduced (Subramanian et al. 2011). It was also investigated that Soapnut oil methyl esters (SNME) and Jatropha oil methyl esters (JME) showed complimentary fuel properties and hence a blending ratio of 35:65 by weight of SNME-JME can compensate high cold filter plugging point (CFPP) of SNME and poor oxidation stability of JME to satisfy all specifications of biodiesel (Chen et al. 2012). It was reported that dual biodiesel blends of Pongamia pinnata oil and Mustard oil with diesel can be used in a single cylinder diesel engine. It was also found that calorific values of dual biodiesel blends with diesel were found to be closer to that of diesel, which was more than single biodiesel blend with diesel (Srithar et al. 2014).

After the study of the review, it may be concluded that Karanja Biodiesel and Linseed Biodiesel could be used as a potential source of fuel in diesel engines individually and the mixture of its oils may produce biodiesel. Karanja oil has high free fatty acid content which requires two step acid base transesterification for biodiesel production. Linseed Oil has low free fatty acid content which produces biodiesel with 88-96\% yields by single step alkaline transesterification. Karanja oil has poor cold flow properties, whereas Linseed oil has improved cold flow properties. Karanja oil contains a high percentage of saturated fatty acids, whereas Linseed oil contains a high percentage of unsaturated fatty acids. Linseed oil is also highly viscous. To offset these aspects of oil properties, a novel approach is used to mix these oils and produce biodiesel to make it commercially viable and popular fuel. However, evaluation of performance characteristics and smoke emission from biodiesel produced from a mixture of Karanja and Linseed has not been reported yet. Since these oils can be produced in various regions on a large scale, it is the need of the time to know about the consequences of mixture by evaluating and analyzing the performance parameters and smoke emission using its biodiesel in a diesel engine. The objective of this research is to evaluate the performance characteristics and smoke emissions of biodiesel obtained from the alkaline transesterification of the mixture of Karanja and Linseed Oils.

\section{Materials and Methods}

\subsection{Biodiesel Production}

Karanja and Linseed Oil were purchased from the local market in New Delhi, India. 50\% Karanja Oil and $50 \%$ Linseed Oil by weight were taken together and mixed. This mixture was transesterified with methanol at 6:1 molar ratio (alkaline transesterification). Reaction time was 60 minutes with the use of $2 \%$ wt $\mathrm{KOH}$ as catalyst. $78.2 \%$ of biodiesel yield was achieved (Mohite et al. 2016).

\subsection{Experimental Setup}

Single cylinder, four stroke, water cooled, direct injection diesel engine was used to perform experiments for the evaluation of performance \& smoke emission characteristics. Engine loading was provided by an Eddy current dynamometer. A panel box containing an air box, dual fuel tank for fuel test, manometer, fuel measuring unit, transmitters for air \& fuel flow measurements, process indicator and engine indicator was used in this experiment. Rotameters were used to measure the cooling water and calorimeter water flow. Software "Engine soft LV" was used for this purpose. The Schematic diagram of engine set up is shown in Fig.1. The specification of diesel engine is shown in table 2 .

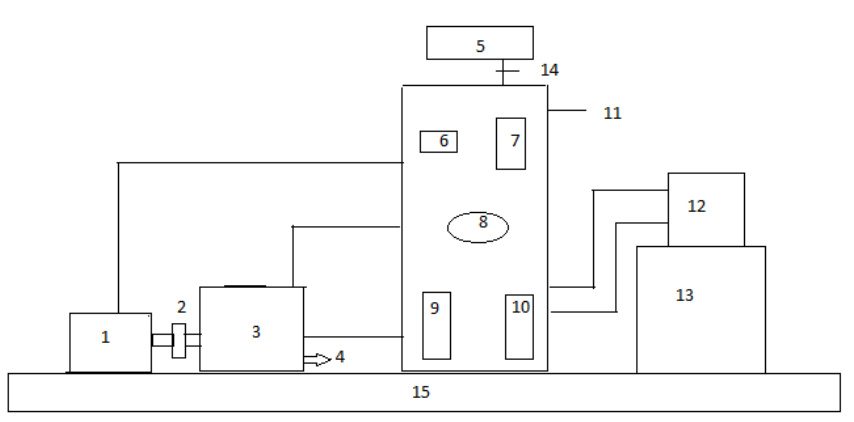

Fig. 1 Schematic diagram of diesel engine test set up

(1)Eddy current dynamometer, (2) Engine coupling, (3) Diesel engine, (4) Exhaust, (5) Dual fuel tank, (6) Engine speed indicator, (7) Fuel level indicator, (8) Load select knob, (9) Engine rotameter, (10) Calorimeter rotameter, (11) Control panel box, (12) Computer with data acquisition system, (13) Power supply, (14) Fuel supply valve, (15) Foundation bed. 
Table 2

Specification of diesel engine

$\begin{array}{ll}\text { Make } & \text { Kirloskar, India } \\ \text { Number of Cylinder } & \text { One } \\ \text { Type } & \text { Four Stroke } \\ \text { Bore } & 87.5 \mathrm{~mm} \\ \text { Stroke } & 110 \mathrm{~mm} \\ \text { Compression Ratio } & 18: 1 \\ \text { Capacity } & 661 \mathrm{cc}\end{array}$

\subsection{Experimental Test Procedure}

Engine Soft LV software was used to record various performance characteristics of the diesel engine at a compression ratio of 18 and varying the brake power from $0.5 \mathrm{~kW}$ to $3.5 \mathrm{~kW}$ (rated load) at a $1500 \mathrm{rpm}$ constant speed. Smoke opacity was measured by the AVL Smoke meter. Biodiesel was produced from the mixture of equal quantities of Karanja and Linseed oils by weight with alkaline transesterification and then its blends of $10 \%, 20 \%$ and $30 \%$ on a volumetric basis with diesel fuel were prepared in the Laboratory. The calorific values, densities and viscosities of diesel and biodiesel blended fuel were measured with Bomb Calorimeter, Hydrometer and Redwood Viscometer respectively and these are shown in Table 3.

Table 3

Important properties of test fuels

$\begin{array}{lcccc}\begin{array}{l}\text { Name of } \\ \text { Property }\end{array} & \text { B10 } & \text { B20 } & \text { B30 } & \text { Diesel } \\ \begin{array}{l}\text { Viscosity (cS)t } \\ \text { Density }\left(\mathrm{kg} / \mathrm{m}^{3}\right)\end{array} & 854.2 & 3.4 & 3.6 & 2.8 \\ & 858.5 & 862.7 & 850 \\ \begin{array}{l}\text { Calorific Value, } \\ \text { (MJ/Kg) }\end{array} & 43.1 & 42.5 & 41.9 & 43.7\end{array}$

\section{Results and Discussion}

Experiments were conducted at the constant speed of $1500 \mathrm{rpm}$ by varying loads. Neat diesel was tested initially. Then, mix oil biodiesel blends of 10 percent, 20 percent and 30 percent with diesel were tested. The results of the experiments are discussed below:-

\subsection{Brake Thermal Efficiency}

The ratio of work output to the amount of fuel energy supplied is called brake thermal efficiency of an engine. It is also called fuel conversion efficiency (Heywood 2012). Maximum and minimum values for BTE are found to be $29.72 \%$ and $27.92 \%$ for diesel and B30 at $3.5 \mathrm{~kW}$ load respectively. BTE is found to be $28.76 \%$ for $\mathrm{B} 10$ at $3.5 \mathrm{~kW}$ load. The maximum reduction in BTE is found to be $6.05 \%$ between diesel and B30 at $3.5 \mathrm{~kW}$ loads among all tested fuels and loads.

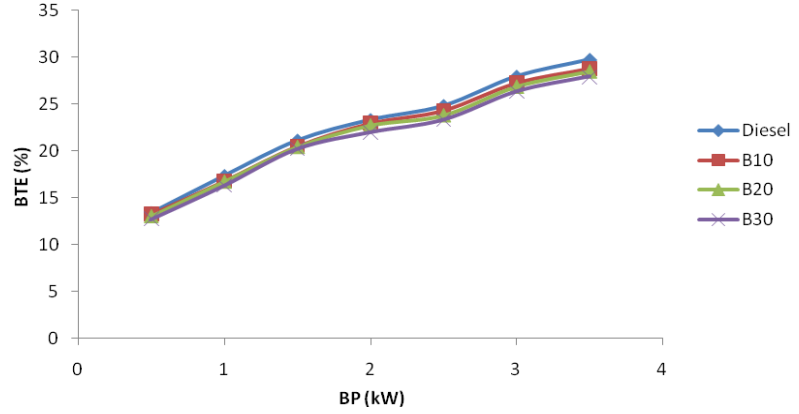

Fig.2 Brake thermal efficiency vs brake power

It is reported that diesel has highest BTE in comparison to all biodiesel blends. The lower BTE of biodiesel as compared to that of diesel may be attributed due to lower calorific value of biodiesel (Baiju et al. 2009).

\subsection{Brake Specific Fuel Consumption}

It is observed that there is decreased in BSFC as the load increases for diesel and biodiesel blends. This may be attributed due to decrease in heat losses at higher loads which leads to reduction in fuel requirement as compared to increase in brake power proportionally for engine operation. The results show $13.04 \%$ and $4.34 \%$ increase in BSFC for B30 and B10 as compared to that of diesel at $3.5 \mathrm{~kW}$ respectively. It is observed that BSFC increases with increase in biodiesel concentration in biodiesel blended fuel due to higher viscosity and lower heating value of biodiesel blends (Amarnath \& Prabhakaran 2012). It is also observed that BSFC of biodiesel blends is higher than diesel. This may be attributed due to consumption of more fuel to develop same power output as that of diesel because of the lower heating value of biodiesel blends (Baiju et al. 2009).

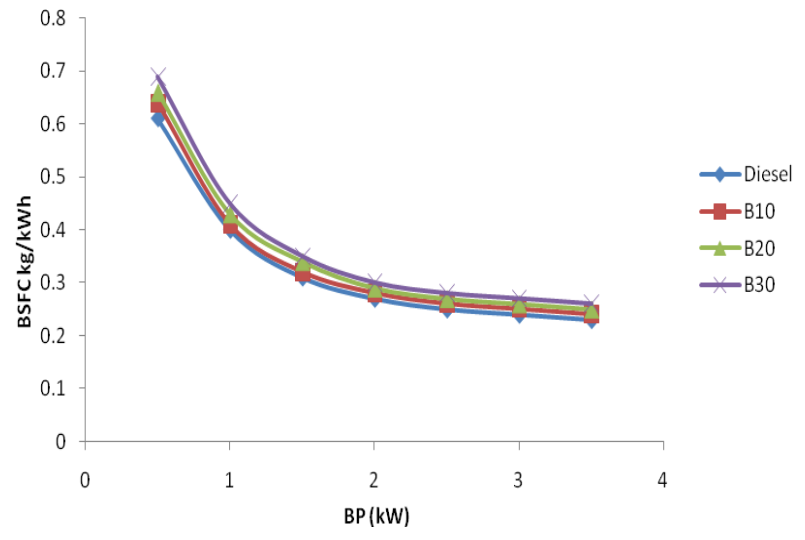

Fig.3 Brake specific fuel consumption vs brake power 


\subsection{Brake Specific Energy Consumption}

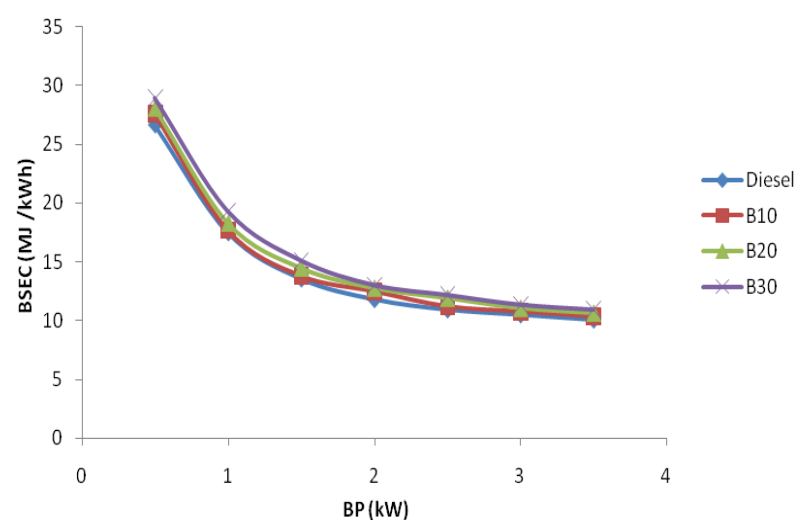

Fig.4 Brake specific energy consumption vs brake power

The product of BSFC and calorific value may be defined as BSEC. BSEC may also be defined as the energy input, which is required to produce unit brake power. BSEC facilitates correct evaluation for capability of diesel engine with blended fuel having different densities and calorific values (Fattah et al. 2014; Imtenan et al. 2015). It is found that B30 has higher BSEC than that of other tested fuels. The results show $8.52 \%$ and $2.95 \%$ increase in BSEC for B30 and B10 as compared to diesel at $3.5 \mathrm{~kW}$ respectively. BSEC decreases with the increase in loads due to decrease in BSFC. Biodiesel blends are reported to have slightly higher values of BSEC than that of diesel. It is found that the BSEC increases with the concentration of biodiesel in the blended fuel due to lower calorific value of biodiesel than that of diesel (Sahoo et al. 2009).

\subsection{Exhaust Gas Temperature}

The results show $6.9 \%$ and $0.36 \%$ increase in EGT for B30 and B10 as compared to that of diesel at $3.5 \mathrm{~kW}$ respectively. EGT increases with increase in load and also

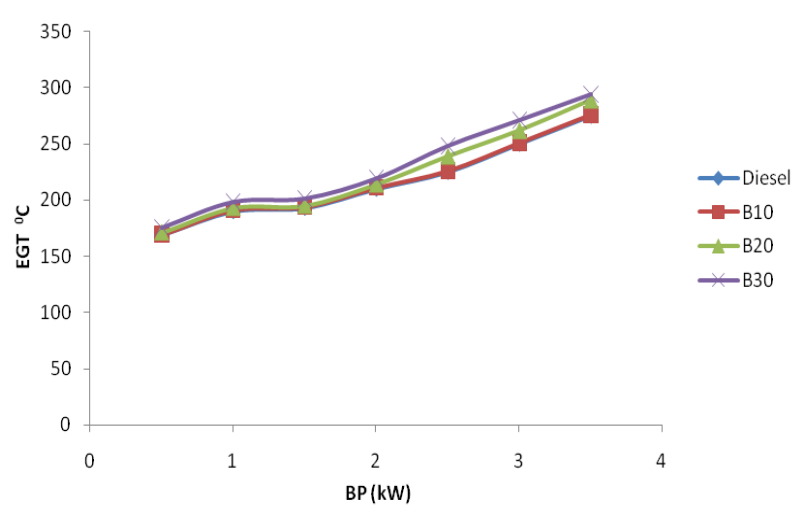

Fig.5 Exhaust gas temperature vs brake power with the concentration of biodiesel in blended fuel. B30 has a higher EGT than other fuels. Higher values of EGT are attributed due to the higher flame temperature of biodiesel as compared to that of diesel (Datta et al. 2014).

\subsection{Mechanical Efficiency}

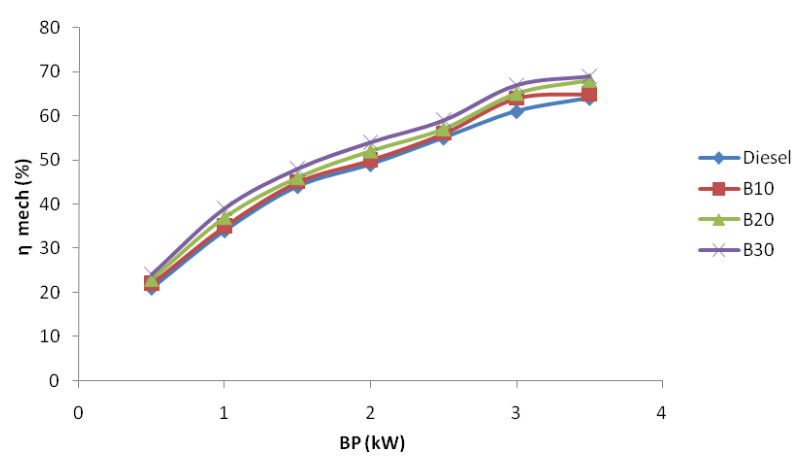

Fig. 6 Mechanical Efficiency vs brake power

Mechanical efficiency is defined as the ratio of brake work at the crankshaft to indicated work in the combustion chamber of an engine. The results show 7.81\% and $1.56 \%$ increase in mechanical efficiency for B30 and B10 as compared to that of diesel at $3.5 \mathrm{~kW}$ respectively. Mechanical efficiency is found to be increased with the increase of biodiesel concentration in the blended fuel as compared to that of diesel. This may be attributed due to better lubricity characteristics of biodiesel as compared to that of diesel and hence, B30 has a higher mechanical efficiency among all tested fuels (Balusamy \& Marappam 2007).

\subsection{Volumetric Efficiency}

The maximum amount of air input into the cylinder during each cycle determines the power and performance of an engine.

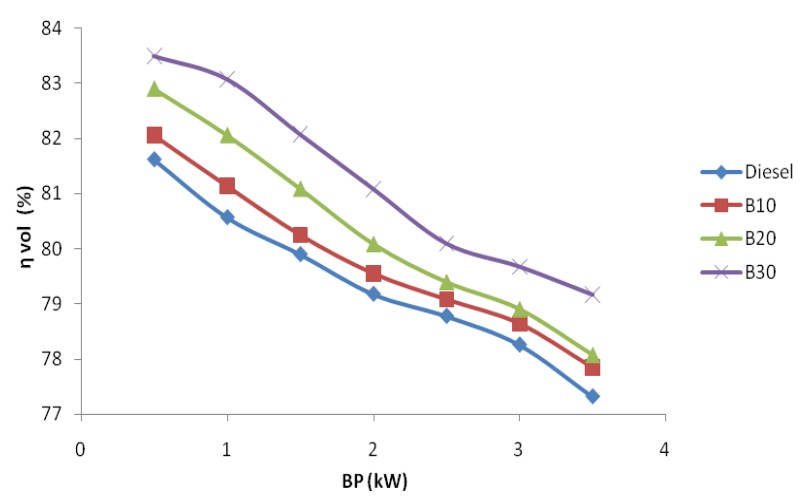

Fig.7 Volumetric efficiency vs brake power

The higher the quantity of air input, higher fuel quantity can be burned with higher energy conversion into power output. Density of atmospheric air multiplied by 
cylinder displacement volume is the mass of air which should be consumed for each cycle in an engine ideally (Pulkrabek 2014). Volumetric efficiency measures the effectiveness of the induction process of an engine and is defined as the ratio of volume flow rate of air into the intake system of an engine to the rate of volume displacement by a piston (Heywood 2012). The results show $2.37 \%$ and $0.67 \%$ increase in volumetric efficiency for B30 and B10 as compared to that of diesel at $3.5 \mathrm{~kW}$ respectively. Volumetric efficiency is found to be reduced with the increase in brake power due to reduction in $A / F$ ratio subsequently. There is a rise of temperature of incoming fresh air in the cylinder due to higher EGT. B30 has the highest EGT among all tested fuels and this causes decrease in the density of incoming fresh air due to rise in temperature. This results in an increase in the actual consumption of air, which causes an increase in volumetric efficiency (Balusamy \& Marappam 2007; Kumar \& Binnal 2012).

\subsection{Air-Fuel Ratio}

Air fuel ratio is defined as the ratio of air mass flow rate to fuel mass flow rate in an engine (Heywood 2012). A/F ratio is found to be reduced with the increase in load due to increase in the requirement of fuel quantity. The results show $9.38 \%$ and $2.88 \%$ increase in Air-fuel ratio for B30 and B10 as compared to that of diesel at $3.5 \mathrm{~kW}$ respectively. Biodiesel blends have a higher $\mathrm{A} / \mathrm{F}$ ratio as compared to diesel. B30 has a higher $\mathrm{A} / \mathrm{F}$ ratio among all tested fuels. This may be attributed due to higher volumetric efficiency of biodiesel (Kumar \& Binnal 2012).

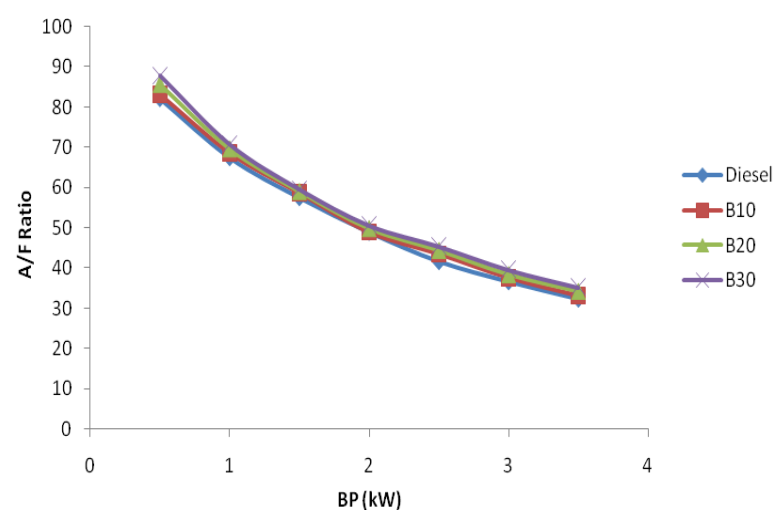

Fig.8 Air-Fuel ratio vs brake power

\subsection{Smoke Opacity}

Smoke opacity increases with increase in load for all tested fuels. This may be attributed due to more consumption of fuel at higher loads. The results show $28.94 \%$ and $10.23 \%$ reduction in smoke opacity of B30 and B10 as compared to that of diesel at a load of $3.5 \mathrm{~kW}$ respectively.

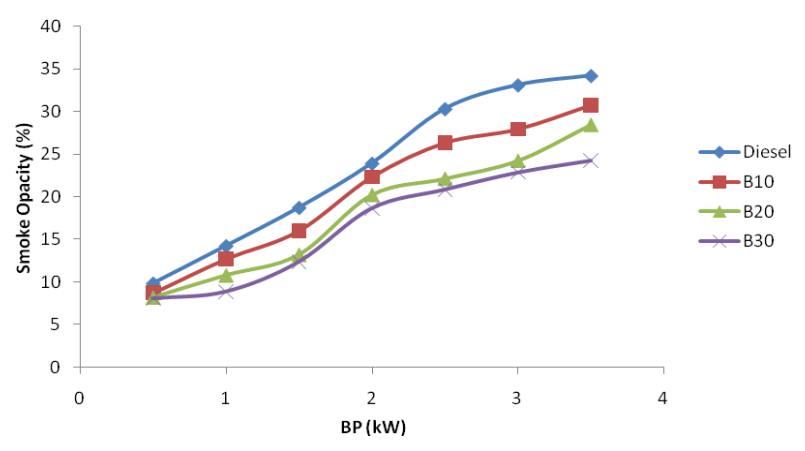

Fig.9 Smoke opacity vs brake power

Biodiesel blends have a lower smoke opacity as compared to diesel because of the presence of oxygen molecules in biodiesel, which enhance the combustion process resulting in decrease in smoke emissions (Prabhu \& Anand 2015).

\section{Conclusions}

In this experimental study, biodiesel was prepared from a mixture of Karanja and Linseed oils and its blends were compared with diesel fuels. Based on this study, the main result of performance characteristics with smoke emission is summarized as follows:-

- BTE was found to be decreased with the concentration of biodiesel in blended fuel and B10 was found to have BTE values closer to that of diesel. BTE was found to be $28.76 \%$ for B10 at $3.5 \mathrm{~kW}$ load. The maximum reduction in BTE was found to be $6.05 \%$ between diesel and B30 at $3.5 \mathrm{~kW}$ loads among all tested fuels and loads.

- BSFC and BSEC were found to be higher for biodiesel blends as compared to that of diesel and increases with the concentration of biodiesel in blended fuel.

- EGT, Mechanical Efficiency and Volumetric Efficiency were found to be higher for biodiesel blends as compared to that of diesel and increases with the concentration of biodiesel in blended fuel. EGT, Mechanical Efficiency and Volumetric Efficiency for B30 were found to be increased by $6.9 \%, 7.8 \%$ and $2.37 \%$ as compared to that of diesel at $3.5 \mathrm{~kW}$ load respectively. EGT, Mechanical Efficiency and Volumetric Efficiency for B10 were found to be increased by $0.36 \%, 1.56 \%$ and $0.67 \%$ as compared to that of diesel at $3.5 \mathrm{~kW}$ load respectively.

- Smoke emissions were found to be considerably reduced with the concentration of biodiesel in blended fuel. Smoke opacity was found to be reduced up to $28.94 \%$ and $10.23 \%$ for B30 and 


\section{B10 in comparison to diesel at $3.5 \mathrm{~kW}$ load} respectively.

Experimental investigation has revealed that biodiesel produced from a mixture of Karanja and Linseed oils can be successfully used in diesel engines without any engine modification and B10 was found to be an optimum biodiesel blend in terms of brake thermal efficiency. Smoke opacity was also found to be reduced with blends.

\section{Acknowledgment}

I am grateful to Delhi Technological University, India for technical support for my research work. I am also thankful to Dr. Amit Pal for his cooperation during the experimental work.

\section{References}

Abbaszaadeh, A., Ghobadian, B., Omidkhah, M.R., \& Najafi, G. (2012) Current biodiesel production technologies: a comparative review. Energy Conversion \& Management, 63,138-148.

Amarnath,H.K., \& Prabhakaran, P. (2012) A study on the thermal performance and emission of a variable compression ratio diesel engine fuelled with karanja biodiesel and the optimization of parameters based on experimental data. International Journal of Green Energy, 9, 841-863.

Atabani, A. E., Silitonga, A.S., Ong, H.C., Mahlia, T.M.I., \& Masjuki, H.H. (2013) Non-edible vegetable oils: a critical evaluation of oil extraction, fatty acid compositions, biodiesel production, characteristics, engine performance and emissions production. Renewable and Sustainable Energy Reviews, 18, 211-245.

Baiju, B., Naik, M.K., \& Das, L.M. (2009) A comparative evaluation of compression ignition engine characteristics using methyl and ethyl esters of karanja oil. Renewable Energy, 34, 1616-1621.

Balusamy, T. \& Marappam, R. (2007) Performance evaluation of direct injection diesel engine with blends of Thevetia Peruviana seed oil and diesel. Journal of Scientific and Industrial Research, 66, $1035-1040$

Barnwal, B.K., \& Sharma, M.P. (2005) Prospects of biodiesel production from vegetable oils in India. Renewable and Sustainable Energy Reviews, 9, 363-378.

Bhuiya, M.M.K., Rasul, M.G., Khan, M.M.K., Ashwath, N., \& Azad, A.K. (2016) Prospects of $2^{\text {nd }}$ generation biodiesel as a sustainable fuelpart 1 selection of feedstocks, oil extraction technologies and conversion technologies. Renewable and Sustainable Energy Reviews, 55, 1109-1128.

Bora, D. K., Das, L. M., \& Babu, M. K. G. (2008) Performance of a mixed biodiesel fuelled diesel engine. Journal of Scientific and Industrial Research, 67, 73-76.

Chen,Y.H., Chiang, T.H. \& Chen, J.H. (2012) An optimum biodiesel combination: Jatropha and soapnut oil biodiesel blends. Fuel, 92(1), 377-380.

Datta, A., Palit, S. \& Mandal, B. K. (2014) An experimental study on the performance and emission characteristics of a CI engine fuelled with Jatropha Biodiesel and its blends with diesel. Journal of Mechanical Science and Technology, 28 (5), 1961-1966.

Dhar, A., \& Agarwal, A. K. (2014) Performance, emission and combustion characteristics of Karanja Biodiesel in a tranportation engine. Fuel, 119,70-80.

Dixit, S., Kanakraj, S., \& Rehman, A. (2012) Linseed oil as a potential resource for biodiesel: a review. Renewable and Sustainable Energy Reviews, 16, 4415-4421.
Fattah, I.M.R., Masjuki, H.H., Kalam, M.A., Wakil, M.A., Ashraful, A.M., \& Shahir, S. A. ( 2014) Experimental investigation of performance and regulated emissions of a diesel engine with Calophylum inophyllum biodiesel blends accompanied by oxidation inhibitors. Energy Conversion and Management, 83, 232240.

Gangil, S., Mewar, C., Singh, R. K., \& Modhera, B. (2015) Influence of acid catalyst on two step transesterification of Karanja Oil with high free fatty acid. Biofuels, 6 (5-6), 377-381.

Guzatto, R., Martini, T. L. D.,\& Samios, D., (2011) The use of a modified TDSP for biodiesel production from Soybean, linseed \& waste cooking oil. Fuel Processing Technology, 92 (10), 20832088.

Halder, S., Sakthivel, S., Jayaraj, K.M., \& Gupta, P.D. (2014) Studies of Transesterification of Karanja (Pongamia pinnata) oil in a packed reactor. Chemical Engineering Communications, 201, 88-101.

Heywood, J. B. (2012) Internal Combustion Engine Fundamentals, $3^{\text {rd }}$ reprint, Tata Mcgraw Hill.

Imtenan, S., Masjuki, H.H., Varman, M., Fattah, I.M.R., Sajjad, H., \& Arbab, M.I. (2015) Effect of n-butanol and diethyl ether as oxygenated additives on combustion emission performance characteristics of a multiple cylinder diesel engine fuelled with diesel - jatropha biodiesel blend. Energy Conversion and Management, 94, 84-94.

Jaichandar, S., \& Annamalai, K. (2012) Effects of open combustion chamber geometries on the performance of Pongamia biodiesel in a DI diesel engine. Fuel, 98, 272-279.

Jena, P. C., Raheman, H., Kumar, G.V.P. \& Machavaram, R. (2010) Biodiesel production from mixture of mahua and simarouba oils with high free fatty acids. Biomass and Bioenergy, 34,11081116.

Kumar D. J. \& Binnal, P. (2012) Performance evaluation of a single cylinder diesel engine fuelled with biodiesel produced from pumpkin oil. Journal of Scientific and Industrial Research, 71, 7578.

Kumar, P., Sharma, M. P., \& Dwivedi, G. Impact of ternary blends of biodiesel on diesel engine performance. Egyptian Journal of Petroleum, In Press, available online $7^{\text {th }}$ Dec,2015.

Kumar, R., Tiwari, P., \& Garg, S. (2013) Alkali Transesterification of linseed oil for biodiesel production. Fuel, 104, 553-560.

Martini, D. D. S., Braga, B. A., \& Samios, D. (2009) On the curing of linsed oil epoxidized methyl esters with different cyclic dicarboxylic anhydrides. Polymer, 50, 2919-2925.

Mohite, S., Kumar, S. Maji S.\& Pal, A. (2016) Production of Biodiesel from a Mixture of Karanja and Linseed Oils: Optimization of process parameters.Iranica Journal of Energy and Environment, $7(1), 12-17$

Nakpong, P., \& Wootthikanokkhan, S. (2010) High free fatty acid coconut oil as a potential feedstock for biodiesel production in Thailand. Renewable Energy, 35, 1682-1687.

Ozcanli, M., \& Serin, H. (2011) Evaluation of Soybean/Canola/Palm biodiesel mixture as an alternative diesel fuel, Journal of Scientific and Industrial Research,70, 466-470.

Pal, A., Kachwaha, S.S., Maji, S., \& Babu, M.K.G. (2010) Thumba (Citrullus colocyntis) seed oil: a sustainable source of renewable energy for biodiesel production. Journal of Scientific and Industrial Research, 69,384-389.

Popa, V. M., Gruia, A., Raba, D.N., Dumbrava, D., Moldovan, C., Bordean, D., \& Mateescu, C. (2012) Fatty acids composition and oil characteristics of Linseed (Linum Usitatissimun L) from Romania. Journal of Agroailimentary Processes and Technogies, 18 (2), 136140.

Prabhu, A. \& Anand, R.B. (2015) Inhibition of NO emission by adding antioxidant mixture in Jatropha biodiesel on the performance and emission characteristics of a CI engine. Frontiers in Energy, 9 (2), 238-245.

Puhan, S., Jegan, R., Balasubbramanian, K., \& Nagarajan, G. (2009) Effect of injection pressure on performance, emission and combustion characteristics of high linolenic in seed oil methyl ester in a DI diesel engine. Renewable energy, 34 (5), 1227-1233.

Pulkrabek, W. W. (2014) Engineering Fundamentals of the Internal Combustion Engine, II Edition, Prentice Hall. 
Raheman, H., Jena, P.C., \& Jadhav, S.S. (2013) Performance of a Diesel Engine with Blends of Biodiesel (from a mixture of oils) and HighSpeed Diesel. International Journal of Energy and Environmental Engineering , 4:6

Rath, S., Kumar, S., \& Singh, R.K. (2011) Performance and emission analysis of blends of Karanja methyl ester with diese in a Compression Ignition Engine. International Journal of Ambient Energy, 32 (3), 161-166.

Saha, R. \& Goud, V.V. (2015) Ultrasound assisted transesterification of high free fatty acids Karanja oil using heterogeneous base catalysts. Biomass Conversion and Biorefinery, 5,195-207.

Sahoo, P.K., Das, L.M., Babu, M.K.G., Arora, P., Singh, V.P., Kumar, N.R., \& Varyani, T.S. (2009) Comparative evaluation of performance and emission characteristics of Jatropha, Karanja and Polanga based biodiesel as fuel in a tractor engine. Fuel, 88, 1698-1707.

Sinha, S., Agarwal, A. K., \& Garg, S. (2008) Biodiesel development from rice bran oil: Transesterification process optimization and fuel characterization. Energy Conversion \& Management, 49, 1248-1257.

Srithar, K., Balasuramanian, K.A., Pavanden, V. \& Kumar, B.A. (2014) Experimental investigations on mixing of two biodiesels blended with diesel as alternative fuel for diesel engines. Journal of King Saud University, Article in Press.

Subramanian, R., Rajandiran, G., Venkatachalam, R., Nadunchezhian, N. \& Mayilsamy,K. (2011) Studies on performance and emission characteristics of multicylinder diesel engine using hybrid fuel blends as fuel, Journal of Scientific and Industrial Research, 70, 539-543.

Yogish, H., Chandrashekara, K. \& Kumar, M.R.P. (2012) Optimization of experimental conditions for composite biodiesel production from transesterification of mixed oils of Jatropha and Pongamia. Heat and Mass Transfer, 48 (11), 1955- 1960. 